\title{
Beyond the Polar Code: Enhancing Seafarer Safety along the Northern Sea Route
}

\author{
Stefan Kirchner* \\ University of Lapland \\ 8 Yliopistonkatu, Rovaniemi, P.O. Box 122, \\ 96101, Finland
}

Received 20.06.2017, received in revised form 28.02.2018, accepted 14.03.2018

No part of the world is experiencing climate change at a rate as fast as the Arctic. Within years, traditional ways of life are becoming impossible to maintain. Everybody who is living and working in the Arctic has to adapt to rapidly changing realities. Many dangers which are common to the Arctic remain persistent while new dangers emerge. In addition, climate change leads to new actors entering the Arctic region. This includes also seafarers who are working on ships which are merely going through the Arctic, for example along Russia's Northern coast, the so called Northern Sea Route or North-East Passage (in analogy to the North-West Passage). Crews as well as individual seafarers without prior Arctic experience can be particularly under threat. Based on earlier research concerning the need for enhanced seafarer training in the Arctic, this text will show that the Polar Code as it is today is not enough to provide for a (at least relatively) safe working environment on board vessels which are operating in Arctic waters.

Keywords: Shipping, Arctic, Polar Code, STCW.

DOI: 10.17516/1997-1370-0230.

Research area: law.

\section{Introduction}

In the Arctic, climate change is already an obvious reality which impacts the lives of many. Arguably, no other part of the world is as much affected by climate change as the Arctic. This can be felt by those who have lived there for a long time in a number of different ways. At the same time does climate change also mean that the Arctic becomes a travel destination, work place and transit route for many who are not familiar with the Arctic. One example for this is the increase in Arctic shipping, which offers cheaper alternative routes between East Asia and the Eastern coast of North America than through the Panama Canal or around South America and a cheaper and safer route or between East Asia and Europe, avoiding the Suez Canal or the trip around Africa as well as the dangerous waters off Somalia or in the Malacca Strait. While there are economic incentives for shipping companies to choose these routes, the transport of natural resources from the Yamal region and other parts of Siberia by ship also leads to an increase in Arctic shipping. Other factors which contribute to an increase in

(C) Siberian Federal University. All rights reserved

* Corresponding author E-mail address: stefan.kirchner@ulapland.fi 
shipping in polar regions are based on increasing accessibility of these extreme regions of the Earth as well. This can include more maritime tourism but also attempts to exploit natural resources in parts of the world which until recently were inaccessible but which are now targeted due to a combination of climate change and technological developments, for example oil and gas fields in Russia's northernmost regions and in the Arctic Ocean.

Shipping is, due to its global character, an international field of work. Today, many of the worlds 1-2 million seafarers come from countries which have emerged as the new seafarer nations, including e.g. Indonesia, the Philippines, Kiribati or Ukraine. As the Arctic climate changes, some risks in the Arctic change while some stay the same. For many seafarers who are traveling and working in the Arctic for the first time, this environment provides specific challenges. This can lead to risks for human life and health.

The Polar Code, ${ }^{1}$ which entered into force on 1 January 2017, aims to deal with some of these dangers and seeks to limit the risks to human safety as well as to the environment by imposing new standards on shipping. While many norms in international shipping law are rather technical in nature, the Polar Code, which has been created in the contexts of both the International Convention for the Safety of Life at $\mathrm{Sea}^{2}$ (SOLAS) and the International Convention for the Prevention of Pollution from Ships ${ }^{3}$ (MARPOL) ${ }^{4}$ also has a "Human Dimension". ${ }^{5}$ It is this perspective which will form the point of departure for this text.

In this text the regulatory content of the Polar Code will be presented. In the following, some areas will be identified in which human safety can be enhanced by measures which are built on the Polar Code but which are not yet contained in it. Particular emphasis will be placed on the issue of the training of seafarers, which is regulated in the Standards on Training Certification and
Watchkeeping Convention ${ }^{6}$ (STCW). Attention will also be given to the Maritime Labour Convention $^{7}$ (MLC), which protects the rights of seafarers as workers. Selected problem areas will be presented and it will be shown how international law can be used to improve the lot of seafarers, in particular those who are newcomers to a rapidly changing Arctic Ocean.

\section{The Polar Code}

It is the aim of the Polar Code as a legal instrument "to provide for safe ship operation and the protection of the polar environment by addressing risks present in polar waters". ${ }^{8}$ In relation to other instruments enacted under the auspices of the IMO the Polar Code is meant to fill regulatory gaps ${ }^{9}$ and contains both binding and non-binding norms. ${ }^{10}$

The risks the Polar Code is meant to deal with are outlines in paragraph 3 and include issues such as freezing surfaces on vessels, ${ }^{11}$ which lead to an increasing risk of falls on board, which in turn is a major source of injuries for seafarers, but also the lack of familiarity of seafarers with polar conditions, ${ }^{12}$ e.g. the long periods of light or darkness or cold temperatures,${ }^{13}$ but also the remoteness from land and infrastructure, ${ }^{14}$ which will be addressed in a moment. While ice is an important risk factor in polar waters, ${ }^{15}$ it is far from the only risk. The Polar Code addresses both technical issues concerning vessels and questions regarding seafarers, such as training and manning, although not all risks can really be trained for. Personal experience and getting accustomed to polar conditions, such as long periods of light or darkness are essential to be able to function well in one's assigned role on board a vessel. The polar regions of the planet are extreme environments and usually it takes some time to get used to being in such changed circumstances. A simple comparison might be work at high altitudes: when traveling e.g. from 
sea level to higher altitudes in the mountains, it usually takes a few days to get used to the lack of oxygen in the air. During the first days one will likely experience fatigue, headaches etc. Likewise, the human biorhythm will need a few days to get used to the fact that the sun is shining nearly 24 hours a day and that it never gets really dark during the summer months, which is the far more likely time for Arctic shipping. Both the Polar Water Operational Manual, which is obligatory under the Polar Code,${ }^{16}$ and the envisaged training regimes ${ }^{17}$ aim at increasing situational awareness of seafarers who are working in polar waters. Given the numerous new impressions the Arctic Ocean can provide for inexperienced seafarers, this is a clear necessity.

\section{Seafarer Training}

STCW provides globally recognized standards for the training of seafarers. On top of basic training elements for all seafarers and specialized training for particular roles on board a vessel, STCW also includes special rules for seafarers serving on particular kinds of vessels, such as oil tankers. What the STCW system does not yet include are specialized rules for shipping in polar waters. With the entry into force of the Polar Code, this is going to change, although the changes to STCW which have been envisaged in the Polar Code have not yet entered into force. ${ }^{18}$ However, first course providers are already offering trainings ${ }^{19}$ as they are likely to be compulsory by next year. ${ }^{20}$ One major problem with the training requirements, however, is that they will not necessary include practical experience in the Arctic. ${ }^{21}$ The need for training has been emphasized, also by this author, in the past. $^{22}$ It is this practical need which has to be met as quickly and as effectively as possible in order to enable seafarers working in the Arctic to identify risks and to protect themselves and their fellow crew members, passengers and vessels.

\section{Rights of Seafarers and Passengers}

For too long, shipping, and international shipping law, has been too focused on the regulation of technical aspects. While high technical standards are essential for ensuring shipping safety, they should not be seen as a stand-alone-solution. In recent years the human element of international shipping has gained more attention, for examples the rights of seafarers in the aforementioned Maritime Labour Convention and the rights of passengers in the Athens Convention. ${ }^{23}$ Both technical advances and human skills have to go hand in hand when it comes to securing maritime safety, especially in the context of vessels carrying large numbers of passengers, many of whom might not only not be familiar with the Arctic but might also lack sufficient knowledge about safety risks on board ships in general.

\section{Geographical Scope of the Polar Code}

One additional problem concerning the Polar Code is its limited geographical application. In the South, all waters south of $60^{\circ} \mathrm{S}$ are covered, ${ }^{24}$ while the geographical scope is more limited in the Arctic. There the southern limit of the Polar Code in principle also follows $60^{\circ} \mathrm{N}$, with the exceptions of a series of lines from $58^{\circ} \mathrm{N}$ $42^{\circ} \mathrm{W}$ (south of Cape Farewell), between Iceland and Greenland, roughly along Jan Mayen and Bjørnoya to the Russian cape of Kanin Nos, about 200 nautical miles east of Murmansk. ${ }^{25}$ As a result, almost the entire Northern coastline of the Russian Federation is included in the geographical scope of the Polar Code, with the exception of the area west of Kanin Nos, ${ }^{26}$ while the waters around Iceland, along continental Norway and near the Kola peninsula are not included, arguably because they benefit from warmer temperatures due to the Gulf Stream, which transports warm water from the Gulf of 
Mexico to Northern Europe. On one hand this is economically beneficial for local ship operators in Iceland, Norway and the Kola peninsula that their vessels do not necessarily have to comply with the Polar Code, on the other hand this can also conceal a hidden risk: in recent months it has been noted that due to climate change more parts of the Arctic ice shelf are breaking off, which leads to an increase in the number of icebergs in the North Atlantic. ${ }^{27}$ Recently also multi-year ice from the High Arctic has been found to be drifting as far south as the Hudson Bay in May and June of 2017, leading to an usual and dangerous ice presence. ${ }^{28}$

The limited geographical scope of the Polar Code therefore must not be misinterpreted to the effect that Arctic-specific risks such as ice in the water are limited to the Arctic. Rather, risk awareness is necessary for a wider geographical area.

\section{Infrastructure and Skills}

In addition to risk awareness, it is necessary to develop the skills necessary to deal with risks. The Polar Code, as it is today, is not enough to ensure that all seafarers operating in the area as well as adjacent regions are fully aware of all risks and are trained accordingly. In addition to the creation of land-based infrastructure, for example Coast Guard stations, it is essential to enhance the skills of crew members. Even a large increase of the number of coastal installations will only go a limited way when it comes to providing assistance to crews and vessels in the Arctic. The large distances involved and the current limitations imposed on the national budget make it highly unlikely that the Russian Federation will be able to provide the funding for sufficient infrastructure to respond to all potential emergencies along the Northern Sea Route in the foreseeable future.

This makes it imperative for vessels which are operating in Russian Arctic waters to be in communication with other vessels in the region as well (which, due to piloting schemes, is already a well-established practice in the area). In addition, it is necessary for the protection of the safety of seafarers that the skillsets available on board are maximized. This means that crew members should be trained to fulfill multiple tasks and should be familiar e.g. with medical procedures which go beyond the classical emergency measures. While such first aid measures can be sufficient in parts of the world where outside assistance is nearby and e.g. medical experts can be on board by helicopter in a matter of minutes, operations in the Arctic Ocean require additional skills. Some of these skills may be provided for example through telemedicine, but many skills will be need in place, i.e., on board vessels which are operating in the Arctic.

This means that seafarers will have to be familiar with the dangers they will face in the Arctic, some of which are outlined in the Polar Code expressis verbis. ${ }^{29}$ Skill enhancement is a recognized element of safety enhancement. This is even more so the case in the Arctic where knowledge, skills and experience as well as high levels of technical functionality are essential.

\section{Concluding Remarks}

While the eventual entry into force of the relevant changes to the STCW Convention will mean a big step in the right direction, a number of factors need to be taken into account as well. Chief among them is the need for experience. While piloting schemes are obligatory in parts of the Arctic, it should not be assumed that a ship's operator is resolved of all liability once a pilot is engaged. Numerous aspects have to be taken into account when it comes to ensuring the safety of the members of the crew - and, as Arctic tourism is becoming more important - of the passengers. ${ }^{30}$

The problem discussed here touches several core elements of the international law 
of the sea. Together, MLC, STCW, SOLAS and MARPOL form the key conventions of international shipping law, within the overall framework of the modern international law of the sea, which is includes both customary international law and codified legal norms, in particular the United Nations Law of the Sea Convention (LOSC). ${ }^{31}$ This already highlights the central position of the problem at hand in the overall landscape of the modern international law of the sea. The Arctic is not only at the cutting edge of climate change and new technological and environmental developments but also at the cutting edge of the development of the international law of the sea. International law has the potential to improve the lives of people in times of change, in particular globalization. "Globalization is neither uniform nor homogenous, but it is indisputably accelerating the pace and intensity of economic and social interactions at all levels." ${ }^{32}$ Long considered a remote wasteland by dominant players on the international stage, the Arctic is now moving to the forefront of today's economic, political and legal debates. Regional knowledge from the Arctic can be used to improve the situation of people both within and outside the Arctic and Sub-Arctic regions. Through effective, meaningful and practical regulation on international, national and sub-national levels, globalization can be made beneficial for all mankind. In this case, international shipping law provides an opportunity to support seafarers, who have too long been overlooked in global shipping business. By utilizing existing frameworks and taking into account local realities in the Arctic and current and future technological challenges, international shipping law can become an important tool for the protection of human lives (in particular the lives of those who work far from home in order to ensure the continued operation of today's global economy based on free trade and enterprise) as well as of the natural environment of the Arctic which is already under considerable threat today.

The proposed changes to STCW are a step in the right direction but more practical experience should be required of seafarers. In addition to Arctic-specific skills, seafarers who are working on board vessels which are operating in the Arctic Ocean (or similarly remote parts of the world) should also be qualified to engage in medical activities which go beyond what is currently required under STCW. Employing modern telecommunication technologies, this can help save the lives of seafarers. In a first step, though, it is now necessary for all actors concerned to ensure that seafarers who are new to the Arctic be given the chance to learn about the particular risks of shipping in the Arctic and about ways to prevent Arctic problems. There is therefore, at this time, an important window of opportunity for Arctic experts to share their knowledge and experience and contribute to the well-being of those who work far from home in order to maintain the exchange of goods which still forms the heart of the global economy.

The author thanks the organizers of the conference "Arctic XXI Century" at the Siberian Federal University in Krasnoyarsk, in particular Anastasia Garmash, for their support during this project. Part of the research for this publication was undertaken during the author's earlier work as Associate Professor for the Law of the Sea at the Faculty of Law of Vytautas Magnus University, Kaunas, Lithuania, and as Lawyer for International Shipping Law at the Federal Maritime and Hydrographic Agency in Hamburg, Germany. This text only reflects the author's private opinion. 
1 Polar Code, MEPC 68/21/Add. 1, Annex 10, pp. 3-55, <http://www.imo.org/en/MediaCentre/HotTopics/polar/Documents/ POLAR\%20CODE\%20TEXT\%20AS\%20ADOPTED.pdf>. (All online sources have last been visited on 13 June 2017).

2 International Convention for the Safety of Life at Sea (SOLAS), 1184 United Nations Treaty Series, No. 18961, <https:// treaties.un.org/doc/Publication/UNTS/Volume\%201184/volume-1184-I-18961-English.pdf>.

3 The 1973 MARPOL is often referred to as MARPOL 73/78, as the text of the 1973 was "absorbed" (Center for International Earth Science Information Network, Protocol of 1978 Relating to the International Convention for the Prevention of Pollution from Ships, <http://www.eisil.org/index.php?t=link_details\&id=1997\&cat=651>) a 1978 Protocol, which can be found at 1340 United Nations Treaty Series, No. 22484, <https://treaties.un.org/doc/Publication/UNTS/Volume\%201340/ volume-1340-A-22484-English.pdf>.

4 John Mauger, "Everything you need to know about the Polar Code", in: Edwin Lampert (ed.), Decoding the Polar Code (2017), 1st ed., Riviera Maritime Media, Enfield (2017), pp. 4-6, at p. 4.

5 Stefan Kirchner, "The Human Dimension of the Polar Code", in: 9 Australian Journal of Maritime \& Ocean Affairs (2017), doi: 10.1080/18366503.2017.1333191, <http://www.tandfonline.com/doi/full/10.1080/18366503.2017.1333191?scroll=top\& needAccess $=$ true $>$.

6 International Convention on Standards of Training, Certification and Watchkeeping for Seafarers (STCW), 1978, 1361 United Nations Treaty Series 2, <https://treaties.un.org/doc/publication/UNTS/Volume\%201361/v1361.pdf>.

7 Maritime Labour Convention, 2006, as amended, <http://ilo.org/wcmsp5/groups/public/---ed_norm/---normes/ documents/normativeinstrument/wcms 554767.pdf>.

Polar Code, Introduction, para. 1

Ibid.

10 John Mauger, "Everything you need to know about the Polar Code", in: Edwin Lampert (ed.), Decoding the Polar Code (2017), 1st ed., Riviera Maritime Media, Enfield (2017), pp. 4-6, at p. 4.

Polar Code, Introduction, para. 3.2.

Polar Code, Introduction, para. 3.7.

Polar Code, Introduction, para. 3.3.

Polar Code, Introduction, para. 3.6.

15 John Mauger, "Everything you need to know about the Polar Code", in: Edwin Lampert (ed.), Decoding the Polar Code (2017), 1st ed., Riviera Maritime Media, Enfield (2017), pp. 4-6, at p. 4; Rob Hindley / James Bond / Andrew Kendrick, "Polaris: Operational risk management guidance under the Polar Code", in: Edwin Lampert (ed.), Decoding the Polar Code (2017), 1st ed., Riviera Maritime Media, Enfield (2017), pp. 8-9, at p. 8; Vanessa Escobar, "Monitoring ice from space reduces risks", in: Edwin Lampert (ed.), Decoding the Polar Code (2017), 1st ed., Riviera Maritime Media, Enfield (2017), pp. 16-17, at p. 16; John Falkingham, "Ice charting provides vital safety support", in: Edwin Lampert (ed.), Decoding the Polar Code (2017), 1st ed., Riviera Maritime Media, Enfield (2017), pp. 18-19.

16 Polar Code, Part I-A, Chapter 2.

17 Polar Code, Part I-A, Chapter 12.

18 David Snider, "Training lags a year behind the code", in: Edwin Lampert (ed.), Decoding the Polar Code (2017), 1st ed., Riviera Maritime Media, Enfield (2017), pp. 22-23, at p. 22.

19 Aboa Mare, Ice Navigation Courses (Polar Code), 2017, <http://training.aboamare.fi/en/events/pd/ice-navigation-coursespolar-code>.

20 David Snider, “Training lags a year behind the code", in: Edwin Lampert (ed.), Decoding the Polar Code (2017), 1st ed., Riviera Maritime Media, Enfield (2017), pp. 22-23, at pp. 22 et seq.

$21 \quad$ Ibid.

22 See e.g. Stefan Kirchner, "Protecting Human Rights in the Arctic through Amendments to the STCW Convention", in: Timo Koivurova / Waliul Hasanat (eds.), 2 Current Developments in Arctic Law (2014), pp. 17-19; Stefan Kirchner / Susanna Pääkkölä, “Polar Health Risks, Seafarers' Rights and Training in International Law”, in: 28 University of San Francisco Maritime Law Journal (2016), pp. 225-235.

23 Athens Convention relating to the Carriage of Passengers and their Luggage by Sea (PAL), 1974, 1463 United Nations Treaty Series, No. 24817, <https://treaties.un.org/doc/Publication/UNTS/Volume\%201463/volume-1463-I24817-English.pdf $>$. PAL was amended by the Protocol of 2002 to the Athens Convention relating to the Carriage of Passengers and their Luggage by Sea, 1974, <http://www.transportrecht.org/dokumente/AthenProt2002e.pdf >. On the new regime and the implementation of PAL in European law see Stefan Kirchner / Grit Tüngler / Jan Martin Hoffmann, "Carrier Liability for Damages incurred by Ship Passengers: The European Union as a Trailblazer towards a Global Liability Regime?”, in: 23 University of Miami International and Comparative Law Review (2015), pp. 193-214.

24 Polar Code, Introduction, Figure 1.

25 Ibid.

26 Ibid.

27 Bryson Masse, "Monster Icebergs Crowding Canada's Coast Are Likely Harbingers of Climate Change”, in: Motherboard, 20 April 2017, <https://motherboard.vice.com/en_us/article/icebergs-newfoundland-canada-climate-change>.

28 Laura Glowacki, "Climate change researchers cancel expedition because of climate change”, in: CBC News Manitoba, 12 June 2017, <http://www.cbc.ca/news/canada/manitoba/climate-change-study-1.4157216>.

29 Polar Code, Introduction, para. 3.

30 On the rights of passengers on board ships in international law see e.g. Stefan Kirchner / Grit Tüngler / Jan Martin Hoffmann, "Carrier Liability for Damages incurred by Ship Passengers: The European Union as a Trailblazer towards a Global Liability Regime?”, in: 23 University of Miami International and Comparative Law Review (2015), pp. 193-214. 
31 United Nations Law of the Sea Convention, 1833 United Nations Treaty Series 2, <http://www.un.org/depts/los/ convention_agreements/texts/unclos/unclos_e.pdf $>$. There has been some debate as to how to best abbreviate the Law of the Sea Convention. In some cases, the abbreviation "UNCLOS" has been used, which can lead to some confusion as the same abbreviation had been used pre-LOSC for the United Nations Conferences on the Law of the Sea, which led to a number of international treaties in this field. In order to avoid confusion, the abbreviation LOSC is preferred in this text, see also Yoshifumi Tanaka, The International Law of the Sea, 2nd ed., Cambridge University Press, Cambridge (2015), p. 12 , there fn. 26.

32 Thomas G. Weiss / David P. Forsythe / Roger A. Coate / Kelly-Kate Pease, The United Nations and Changing World Politics, 5th ed., Westview Press, Boulder (2007), p. 367.

\section{References}

Aboa Mare, Ice Navigation Courses (Polar Code), (2017), available at: <http://training.aboamare. fi/en/events/pd/ice-navigation-courses-polar-code>.

Athens Convention relating to the Carriage of Passengers and their Luggage by Sea (PAL), 1974, 1463 United Nations Treaty Series, No. 24817, available at: <https://treaties.un.org/doc/Publication/ UNTS/Volume\%201463/volume-1463-I-24817-English.pdf>.

Center for International Earth Science Information Network, Protocol of 1978 Relating to the International Convention for the Prevention of Pollution from Ships, available at: <http://www.eisil. org/index.php?t=link_details\&id $=1997 \&$ cat $=651>$.

Vanessa Escobar, "Monitoring ice from space reduces risks", in: Edwin Lampert (ed.), Decoding the Polar Code (2017), 1st ed., Riviera Maritime Media, Enfield (2017), pp. 16-17.

John Falkingham, “Ice charting provides vital safety support”, in: Edwin Lampert (ed.), Decoding the Polar Code (2017), 1st ed., Riviera Maritime Media, Enfield (2017), pp. 18-19.

Laura Glowacki, "Climate change researchers cancel expedition because of climate change", in: CBC News Manitoba, 12 June 2017, <http://www.cbc.ca/news/canada/manitoba/climate-changestudy-1.4157216>.

Rob Hindley / James Bond / Andrew Kendrick, "Polaris: Operational risk management guidance under the Polar Code", in: Edwin Lampert (ed.), Decoding the Polar Code (2017), 1st ed., Riviera Maritime Media, Enfield (2017), pp. 8-9.

International Convention for the Prevention of Pollution from Ships (MARPOL), 1973, and Protocol of 1978 Relating to the International Convention for the Prevention of Pollution from Ships, 1340 United Nations Treaty Series, No. 22484, available at: $<$ https://treaties.un.org/doc/Publication/ UNTS/Volume\%201340/volume-1340-A-22484-English.pdf>.

International Convention for the Safety of Life at Sea (SOLAS), 1184 United Nations Treaty Series, No. 18961, available at: <https:/treaties.un.org/doc/Publication/UNTS/Volume\%201184/volume-1184-I-18961-English.pdf>.

International Convention on Standards of Training, Certification and Watchkeeping for Seafarers (STCW), 1978, 1361 United Nations Treaty Series 2, available at: <https://treaties.un.org/doc/ publication/UNTS/Volume\%201361/v1361.pdf>.

Stefan Kirchner, "New Approaches to the Mitigation of Dry Cargo Liquefaction Risks in Arctic Shipping”, forthcoming (2017).

Stefan Kirchner, "Protecting Human Rights in the Arctic through Amendments to the STCW Convention", in: Timo Koivurova / Waliul Hasanat (eds.), 2 Current Developments in Arctic Law (2014), pp. 17-19.

Stefan Kirchner, "The Human Dimension of the Polar Code", in: 9 Australian Journal of Maritime \& Ocean Affairs (2017), doi: 10.1080/18366503.2017.1333191, available at: <http://www.tandfonline. com/doi/full/10.1080/18366503.2017.1333191?scroll=top\&needAccess=true>. 
Stefan Kirchner / Susanna Pääkkölä, "Polar Health Risks, Seafarers' Rights and Training in International Law", in: 28 University of San Francisco Maritime Law Journal (2016), pp. 225-235.

Stefan Kirchner / Grit Tüngler / Jan Martin Hoffmann, "Carrier Liability for Damages incurred by Ship Passengers: The European Union as a Trailblazer towards a Global Liability Regime?”, in: 23 University of Miami International and Comparative Law Review (2015), pp. 193-214.

Maritime Labour Convention, 2006, as amended, available at: <http://ilo.org/wcmsp5/groups/ public/---ed_norm/---normes/documents/normativeinstrument/wcms_554767.pdf>.

Bryson Masse, "Monster Icebergs Crowding Canada's Coast Are Likely Harbingers of Climate Change”, in: Motherboard, 20 April 2017, available at: <https://motherboard.vice.com/en_us/article/ icebergs-newfoundland-canada-climate-change>.

John Mauger, "Everything you need to know about the Polar Code", in: Edwin Lampert (ed.), Decoding the Polar Code (2017), 1st ed., Riviera Maritime Media, Enfield (2017), pp. 4-6.

Polar Code, MEPC 68/21/Add. 1, Annex 10, pp. 3-55, available at: <http://www.imo.org/en/ MediaCentre/HotTopics/polar/Documents/POLAR\%20CODE\%20TEXT\%20AS\%20ADOPTED. pdf>.

Protocol of 2002 to the Athens Convention relating to the Carriage of Passengers and their Luggage by Sea, 1974, available at: <http://www.transportrecht.org/dokumente/AthenProt2002e.pdf>.

David Snider, “Training lags a year behind the code", in: Edwin Lampert (ed.), Decoding the Polar Code (2017), 1st ed., Riviera Maritime Media, Enfield (2017), pp. 22-23.

Yoshifumi Tanaka, The International Law of the Sea, 2nd ed., Cambridge University Press, Cambridge (2015).

United Nations Law of Sea Convention, 1833 United Nations Treaty Series 2, available at: $<$ http:// www.un.org/depts/los/convention_agreements/texts/unclos/unclos_e.pdf $>$.

Thomas G. Weiss / David P. Forsythe / Roger A. Coate / Kelly-Kate Pease, The United Nations and Changing World Politics, 5th ed., Westview Press, Boulder (2007).

\title{
За рамками Полярного кодекса:
}

\section{повышение уровня безопасности моряков на Северном морском пути}

\author{
С. Кирхнер \\ Лапландский университет \\ Финляндия, 96101, Р.О. Вох 122, Рованиеми, \\ Йулиопистонкату, 8
}

Ни одна другая часть земного шара не сталкивается с такими значительными климатическими изменениями, как Арктика. С течением времени становится невозможным продолжать традиционный образ жизни. Все живущие и работающие в этом регионе вынуждены адаптироваться к стремительно меняющейся реальности. Многие типичные для Арктического региона опасности никуда не исчезают, в то время как появляются новые. Кроме того, изменение климата влечет за собой появление новых субъектов в Арктическом регионе. Среди них 
моряки, плавающие на судах по маршрутам, на которых Арктика является промежуточной точкой пути, например, вдоль Российского северного берега, по так называемому Северному морскому пути. Команды, а также отдельные моряки, не имеющие опьта плавания в Арктических водах, подвергаются опасности. Основываясь на ранее проведенных исследованиях относительно необходимости улучшения уровня подготовки моряков, путешествуюших по Арктике, в данной статье рассматривается несостоятельность Полярного кодекса в том виде, в котором он существует на сегодняшний день, так как он не обеспечивает (хотя бы относительную) безопасность рабочих условий на борту судов, маршруты которых пролегают в Арктических водах.

Ключевые слова: судоходство, Арктика, Полярный кодекс, ПДМНВ.

Научная специильность: 12.00.00-юридические науки. 